\title{
Teaching Reform and Practice of ERP Course Based on OBE-TC Concept
}

\author{
Xiaoyu WANG \\ Dept. of Information management \\ Dalian Neusoft Institute of Information \\ Dalian, China, 0411-84832233 \\ wangxiaoyu@neusoft.edu.cn
}

\author{
Qian WANG \\ Dept. of Information management \\ Dalian Neusoft Institute of Information \\ Dalian, China
}

\author{
Di WU \\ Dept. of Information management \\ Dalian Neusoft Institute of Information \\ Dalian, China
}

\begin{abstract}
Based on the concepts of OBE and TOPCARESCDIO, Dalian Neus oft University of Information proposed the concept of OBE-TC education and teaching reform, aimed at the integration education through knowledge, ability and attitude of the students to cultivate talents with high quality. According to the OBE-TC concept and student centered, information management and information system specialty carries out the comprehensive teaching reform of ERP course by making clear the expected learning effect, designing and implementing curriculum contents and activities, and evaluating learning output. Through the reform of the ERP curriculum based on OBE-TC, students have achieved the knowledge, abilities and qualities required by the profession, thereby enhancing the quality of personnel training.
\end{abstract}

Keywords-OBE-TC; ERP; Curriculum reform; Learning outcome

\section{OBE-TC CONCEPT OF EDUCATION AND TEACHING REFORM}

In order to cultivate high-quality applied professionals, colleges and universities have been continuously deepening the education and teaching reform of the curriculum system. However, there are still problems in the course of curriculum construction, such as unclear curriculum objectives and expected learning results, non-basic implementation of curriculum content, and the inability of the assessment results to evaluate students' learning effects, etc., and thus fail to achieve the knowledge, ability and quality that students should possess. In order to effectively solve this series of problems, Dalian Neusoft University of Information put forward the OBE-TC education reform concept according to the OBE concept and the TOPCARES-CDIO (TC) concept. Take the student as the center, clear the expected learning outcomes of the course and the TC skills needed to achieve, and then targeted the design and implementation of curriculum content and activities, and ultimately through a variety of assessment methods to assess student learning, so as to improve the quality

The 13th Five-Year Plan project for Education Science in Liaoning Province: Research on the results-oriented evaluation model of practice courses (JG18DB031) of teaching, training More application talents.

OBE (Outcomes-based Education), an educational model based on learning output, originated in the 80s of last century, based on the concept of results oriented education. OBE is a structural model for organizing, implementing, and evaluating education centering on expected learning outcomes. There are four main steps: identifying learning outcomes, achieving learning outcomes, evaluating learning outcomes, and using learning outcomes[1].

Based on the standard CDIO idea, Dalian Neusoft University of Information puts forward TOPCARES-CDIO (TC) concept, requiring students to master eight types of knowledge, abilities and attitudes: technical knowledge and reasoning ability (T), open thinking and innovation (O), personal Professionalism (P), Communication and Teamwork (C), Attitude and Practice (A), Responsibility (R), Values and Practice (E), Design, Implementation, and Operation Contribution to Society(S)[2].In the four years of professional study, students form an integrated professional learning system. After graduating from university, it not only masters professional knowledge, but also has corresponding professional ability and quality. In accordance with the school's TOPCARES-CDIO idea, the professional has built an integrated professional construction work flow. Through the implementation of the work flow, it has determined the professional integrated personnel training ability system, and according to the talent cultivation ability system, integrated curriculum design and Project Design.

At present, each school major is in-depth implementing OBE-TC education and teaching reform. First, according to national and professional standards, through the investigation on the industry research and professional stakeholders, to identify the professional training objectives and characteristics, and then determine the professional graduation requirements[3] ; in order to achieve graduation requirements, again through investigation, clear professional training of eight TC ability of students and master degree of each ability, that is, the learning outcomes in the OBE are clear, that is, the 
expected outcomes of learning; in order to reach a defined talent cultivation ability system and achieve the expected learning effect, the professional integrated curriculum and project design and implementation, that is, to identify the expected outcomes of each curriculum and project, and then implement the curriculum and the project, and evaluate according to the evaluation system, so as to achieve professional training objectives, and cultivate more highquality applications Talents.

The Enterprise Resource Planning (ERP) is a new enterprise information management system, ERP has been accepted by more and more enterprises[4]. Since the ERP course is the core curriculum of the information management and information system major of our school, how to make the teaching content of this course conform to the professional training objectives, how to do the OBE-TC teaching reform of this course is very important.

\section{DEFINING INTENDED LEARNING OUTCOMES OF ERP CURRICULUM}

To clarify the learning outcomes of ERP courses is to clarify intended learning outcomes of the curriculum. According to the graduation requirements of information management and information system specialty, we should clarify the general goal of ERP curriculum, the TC ability and the degree of ability to be achieved, and finally determine the expected learning effect of the course.

The theoretical basis of ERP comes from management theory, economics, and accounting related knowledge. Therefore, it requires students to learn relevant management knowledge before studying this course, so as to better learn ERP courses; ERP course is a very practical course, the course not only requires students to master the principles of ERP, but also grasps the whole process of enterprise operations through a specific ERP platform, and further understands theoretical knowledge through practice.

The overall goal of the ERP curriculum is to master management, accounting, and other related knowledge; to understand the basic principles of ERP and ERP implementation methods and understand the development trend of ERP; can use sales, procurement, production, inventory, finance and other ERP knowledge in a typical ERP platform; and analyzes the standard business processes of small and medium-sized enterprises; with the update of knowledge and self-improvement learning desires and good study habits.

According to professional graduation requirements and the overall goals of the ERP curriculum, determine the level of TC abilities achieved in the course and determine the expected learning effect. Intended Learning Outcomes of the ERP curriculum is shown in TABLE I.

TABLE I. INTENDED LEARNING OUTCOMES OF THE ERP CURRICULUM

\begin{tabular}{|c|c|c|c|c|}
\hline Graduation Requirements & Achieved TC Abilities & Weights & $\begin{array}{l}\text { Degree of } \\
\text { mastery }\end{array}$ & Intended Learning Outcomes(ILO) \\
\hline $\begin{array}{l}\text { Master the basic knowledge of modern } \\
\text { enterprise management such as } \\
\text { management, economics, and accounting }\end{array}$ & $\begin{array}{l}\text { 1.3.1Basic knowledge of } \\
\text { modern enterprise } \\
\text { management }\end{array}$ & 0.1 & master & $\begin{array}{l}\text { ILO-1: } \\
\text { Understand the connotation of enterprise } \\
\text { management and related basic concepts }\end{array}$ \\
\hline $\begin{array}{l}\text { Master professional knowledge of } \\
\text { enterprise information project } \\
\text { implementation, consulting, operation and } \\
\text { maintenance }\end{array}$ & $\begin{array}{l}\text { 1.4.1Information } \\
\text { systems(ERP) application of } \\
\text { professional knowledge }\end{array}$ & 0.2 & master & $\begin{array}{l}\text { ILO-2:Mastering business processes related to } \\
\text { procurement, sales, finance, production, inventory, } \\
\text { etc. }\end{array}$ \\
\hline $\begin{array}{l}\text { Have a certain ability to ask questions, } \\
\text { analyze problems and solve problems. }\end{array}$ & 2.2.1 analyze problems & 0.2 & master & $\begin{array}{l}\text { ILO-3:Ability to analyze and solve problems in } \\
\text { enterprise management problems }\end{array}$ \\
\hline \multirow{2}{*}{$\begin{array}{l}\text { Have strong ERP implementation, } \\
\text { consulting and application ability }\end{array}$} & 2.1.1 All-round thinking & 0.1 & understanding & $\begin{array}{l}\text { ILO-4: } \\
\text { Understand the integrated relationship of business } \\
\text { management, with a full range of thinking skills }\end{array}$ \\
\hline & $\begin{array}{l}\text { 3.3.1 Basic information } \\
\text { processing capabilities }\end{array}$ & 0.3 & application & $\begin{array}{l}\text { ILO-5:The ERP platform can be used to conduct } \\
\text { basic management of procurement, sales, finance, } \\
\text { production, inventory and other related business. }\end{array}$ \\
\hline $\begin{array}{l}\text { Has updated knowledge and self- } \\
\text { improvement learning desires and good } \\
\text { study habits }\end{array}$ & $\begin{array}{l}5.1 .2 \text { Learning attitudes and } \\
\text { habits }\end{array}$ & 0.1 & master & $\begin{array}{l}\text { ILO-6:Have good study habits and self-renewal } \\
\text { knowledge }\end{array}$ \\
\hline
\end{tabular}

\section{DESIGN AND IMPLEMENT THE LEARNING TASKS AND ACTIVITIES OF THE ERP COURSE}

Through the design and implementation the learning tasks and activities of ERP curriculum to achieve learning outcomes, achieve the desired learning effect. The ERP course is a comprehensive application course, and the course content is designed from the perspective of the combination of theory and practice. The course is guided by a complete project. The platform is SAP Business One (SBO), an ERP product developed by SAP in the face of SMEs. It guides students to gradually learn the enterprise financial management, procurement management, sales Management, inventory management and production management business processes. And then guide students in the SBO platform to achieve enterprise management business; the design of such practical content has deepened the understanding of ERP theory and enterprise business processes, thereby enhancing students' practical ability.

The ERP curriculum already has teaching resources such as hard copy textbooks, electronic teaching materials, instructional guides, case bases, teaching PPT, practice platform, teaching network system, etc. through the teaching method of heuristic, discussion teaching, the project guide, issue guidance, case teaching, demonstration and experiment, to improve enthusiasm of students' active learning, to cultivate 
their innovative consciousness and spirit. The learning tasks and activities of the ERP course are shown in TABLE II.

TABLE II. THE EXPECTED LEARNING EFFECT OF THE ERP CURRICULUM

\begin{tabular}{|l|l|l|l|}
\hline Expected Learning Effect & Course Content & Method to realize & teaching method \\
\hline \multirow{5}{*}{ ILO-1 } & $\begin{array}{l}\text { The concept and meaning of ERP } \\
\text { The development of ERP } \\
\text { General ledger account } \\
\text { General ledger processing }\end{array}$ & Classroom teaching & $\begin{array}{l}\text { Discussion } \\
\text { Teaching Case }\end{array}$ \\
\hline & $\begin{array}{l}\text { Procurement Management } \\
\text { Sales Management } \\
\text { Financial Management } \\
\text { Production Management } \\
\text { Inventory Management }\end{array}$ & Classroom teaching & $\begin{array}{l}\text { Discussion } \\
\text { Teaching Case }\end{array}$ \\
\hline \multirow{3}{*}{ ILO-3 } & $\begin{array}{l}\text { Preparation for ERP implementation } \\
\text { ERP implementation } \\
\text { ERP project practice }\end{array}$ & $\begin{array}{l}\text { Classroom teaching } \\
\text { ERP project practice }\end{array}$ & $\begin{array}{l}\text { Case } \\
\text { Demonstration } \\
\text { Experiment }\end{array}$ \\
\hline \multirow{2}{*}{ ILO-5 } & ERP systemmodule integration relationship & ERP project practice & $\begin{array}{l}\text { Case } \\
\text { Demonstration } \\
\text { Experiment }\end{array}$ \\
\hline ILO-6 & $\begin{array}{l}\text { Purchase Application } \\
\text { Sales Application } \\
\text { Financial Application } \\
\text { Production Application } \\
\text { Inventory Management }\end{array}$ & ERP project practice & $\begin{array}{l}\text { Demonstration } \\
\text { Experiment }\end{array}$ \\
\hline
\end{tabular}

\section{USING DIVERSIFIED ASSESSMENT METHODS TO EVALUATE STUDENT LEARNING}

The ERP curriculum adopts multiple assessment methods to examine the students' comprehensive ability and quality, and mainly assess students' theoretical knowledge and application ability. Theoretical knowledge assessment focuses on students' mastery of ERP key concepts and principles; the purpose of the application ability assessment method is to turn assessment into an opportunity to stimulate students' interest in learning. Through the usual project practice, students' enthusiasm for learning can be cultivated and teaching effectiveness can be improved.
The ERP curriculum extends traditional end-of-term assessments to formative assessments and summative assessments, that is, $50 \%$ of formative assessments and $50 \%$ of final assessments. Through flexible and diversified exercises and hands-on practice in classrooms and classes, students are given plenty of room to play so that the final exam results are closer to the true level of students. Each assessment has developed a detailed scoring standard, to ensure the students' final learning outcomes are assessed through a diversified assessment. ERP curriculum diversification assessment methods and scoring standards are shown in TABLE III.

TABLE III. ERP CURRICULUM DIVERSIFICATION ASSESSMENT METHODS AND SCORING ST ANDARDS

\begin{tabular}{|c|c|c|c|c|}
\hline Category & $\begin{array}{c}\text { Assessment } \\
\text { project }\end{array}$ & Weights & $\begin{array}{l}\text { Appraised } \\
\text { abilities }\end{array}$ & Scoring Standards \\
\hline \multirow{3}{*}{$\begin{array}{l}\text { Formative } \\
\text { Assessment }\end{array}$} & $\begin{array}{c}\text { Classroom } \\
\text { performance } \\
\text { Answer question }\end{array}$ & $10 \%$ & $\begin{array}{l}1.3 .1 \\
1.4 .1 \\
2.2 .1 \\
5.1 .2\end{array}$ & $\begin{array}{l}\text { Calculate scores based on the degree of difficulty in answering questions and the } \\
\text { correctness of the answer }\end{array}$ \\
\hline & $\begin{array}{l}\text { Practice completed } \\
\text { quality }\end{array}$ & $30 \%$ & $\begin{array}{l}1.4 .1 \\
2.1 .1 \\
2.2 .1 \\
3.3 .1 \\
5.1 .2\end{array}$ & $\begin{array}{c}\text { Basic setting practice :0-4 points } \\
\text { Financial management practices:0-5 } \\
\text { Sales Management Practice:0-6 points according to correctness of practice } \\
\text { ProcurementManagement Practices: } 0-6 \text { points based on the correctness of the } \\
\text { practice } \\
\text { Inventory Management Practice:0-4 } \\
\text { Production Management Practice: } 0-5 \text { points }\end{array}$ \\
\hline & $\begin{array}{l}\text { Project Report } \\
\text { Complete quality }\end{array}$ & $10 \%$ & $\begin{array}{l}1.4 .1 \\
2.1 .1 \\
2.2 .1 \\
3.3 .1 \\
5.1 .2\end{array}$ & $\begin{array}{l}\text { The project report standarddegree:0-2 points } \\
\text { The project conclusion correct degree: } 0-5 \text { points } \\
\text { Questions answered correctly : } 0-3 \text { points }\end{array}$ \\
\hline $\begin{array}{l}\text { Summative } \\
\text { Assessments }\end{array}$ & Final exam & $50 \%$ & $\begin{array}{l}1.3 .1 \\
1.4 .1 \\
2.1 .1 \\
2.2 .1 \\
5.1 .2\end{array}$ & Closed-end closing assessment, accounting for $50 \%$ of the total score \\
\hline
\end{tabular}




\section{CONCLUSION}

With the continuous deepening of the OBE-TC education and teaching reform, the ERP curriculum group will correct and improve the expected effect of the curriculum learning output according to the learning output effect, strengthen the design and implementation of learning task and activity of ERP curriculum, and improve the evaluation standard of learning output, so as to improve student learning effect and improve the teaching quality of the course.

\section{REFERENCES}

[1] Gu Peihua, Hu Wenlong, Lin Peng. "Engineering Education Model Based on Observative Output(OBE): Practice and Exploration of Shantou University",Research in Higher Education of Engineering, pp.27- 37, January ,2014..

[2] Sun Fuquan, Wang Xiaoyu, Wu Di. "IT application-oriented talent training model based on CDIO concept ", Computer Education, pp.3035, November,2010.

[3] Ji Ce, Lei Weimin, Fu Chong. "An exploration of the reform of the Signals and Systems course system based on the OBE education concept”, Education Teaching Forum,pp. 49-50, December,2017.

[4] Wang Xiaoyu, Wu Di, "Enterprise Resource Planning (ERP)", BeiJing:China Railway press, pp.12-27,2011. 